\title{
Pilgrims' Spiritual Practices at The Tomb of Sunan Giri During the Covid Pandemic
}

\author{
Mutimmatul Faidah ${ }^{1, *}$ \\ ${ }^{1}$ Home Economic Department Universitas Negeri Surabaya, Indonesia \\ ${ }^{*}$ Corresponding author.Email: mutimmatulfaidah@unesa.ac.id
}

\begin{abstract}
Sunan Giri is one of Walisongo in Java who was buried in the hills of Giri. Walisongo is the name of the nine ulama' who spread Islam in Indonesia in the 7th century AD. Walisongo is believed to have spiritual virtues so that it becomes an attraction for spiritual pilgrimages for Indonesian Muslims to receive blessings from God. This study aimed to describe the characteristics of the tomb of Sunan Giri and describe the pilgrims' spiritual practices at the tomb. This study used qualitative research with historical and phenomenological approaches. Data were collected by using observation and documentation. The results showed that the tomb of Sunan Giri was at the top of the hill as a symbol of the high position of Wali in front of Allah. The shape of the tomb and its ornaments were a combination of HinduIslamic elements. Another finding showed that there were three types of pilgrims namely individual, individual-lelaku (spiritual behavior), and congregational. The activities carried out were generally reading tawassul, S. Yasin, tahil, and prayer. The purpose of the pilgrims was to pray closer to God, get blessings, and get wasilah/intermediary so that their prayers and wishes were granted by God. Pilgrimage was a medium for fulfilling needs, both material and spiritual. The findings of this study were the continuity of Hindu-Islamic traditions in the form of Wali's tomb and the presence of material and spiritual dimensions in the pilgrimage tradition.
\end{abstract}

Keywords: tomb, spiritual, pilgrimage, blessing

\section{INTRODUCTION}

The development of Islam in Indonesia cannot be separated from the role and presence of Walisongo. Walisongo is the assembly of ulama' (Islamic Scholar) who first spread Islam in Indonesia, along with the establishment of Demak Kingdom as the first Islamic kingdom in Java and the collapse of Hindu-Buddhist Majapahit Kingdom [1]. One of the Walisongo is Sunan Giri. Sunan Giri is also known by several other names, such as Raden Paku, Joko Samudro, or Muhammad Ainul Yaqin.

From a historical perspective, Sunan Giri is the son of Sheikh Maulana Ishaq and Dewi Sekardadu (daughter of King Blambangan) who was born in 1442 AD. Sunan Giri united two aspects of leadership, namely religious and political leaders. As a king, Sunan Giri had the title Prabu Satmoto and ruled the Kingdom of Giri Kedaton in 1487-1506 AD. Sunan Giri became the power holder in Giri with the position of tetumtul khalifatul mukminin (leader of all believers). Sunan Giri found a kedaton (kingdom) on a hill that became known as Giri Kedaton [2]. Giri Kedaton became the center of Islamic religious education (pesantren) as well as the government. In its development, the Giri Islamic boarding school was known as one of the centers for the spread of Islam in Java, even its influence reached Madura, Lombok, Kalimantan, Sulawesi, and Maluku. Giri Kedaton ruled Gresik and its surroundings for several generations until it was finally overthrown by Sultan Agung. Sunan Giri died in $1506 \mathrm{AD}$, and was buried on a hill in a cupola (a roofed building that stands on a tomb) with a very unique Javanese architecture [3].

For Javanese community, Wali is an entity that is part of religion and social life, which plays a central role in Javanese-Islamic mystical piety. Wali is believed to be a person who knows and is close to God. One form of respect for wali is to make a pilgrimage to the tomb. The tomb of Wali is considered sacred because wali accepts supernatural abilities and has karomah (a privilege from 
God). The tomb has its spiritual appeal for Javanese Muslims to make pilgrimages with a specific purpose. At the beginning of the pandemic, from April to July 2020, Sunan Giri's tomb was closed to pilgrims. Provisions for opening and closing graves are in accordance with government regulations. In August 2020 since the enactment of the New Normal, the tomb is gradually opening to pilgrims. Activities at the tomb, both spiritual and economic dimensions occur with the implementation of health protocols. This study aimed to describe the characteristics of the tomb site of Sunan Giri and describe the pattern of pilgrims' spiritual practice in the tomb during the pandemic

\section{METHOD}

This study was qualitative research. The data were obtained by studying artifacts, interviews, and participant observation in the tomb area. This research in March to July 2021. Informants are pilgrims, tomb guards, and tomb managers. Data were analyzed with historical and phenomenological approaches. Data validity with the triangulation method

\section{RESULT AND DISCUSSION}

\subsection{Characteristics of the Tomb of Sunan Giri}

Sunan Giri's tomb is located at the top of a rocky hill. To get to the tomb of Giri, pilgrims have to climb several stairs that total up to 104 pieces. This tomb is located in the village of Giri, Kebomas, Gresik. The Sunan Giri Tomb site is one of the historical heritages of the spread of Islam in Indonesia that has become a religious tourism object [4]. The placement of tombs in high hills is still influenced by elements of Indonesian Hindu culture. The position of the tomb in a high place is a symbol of humanGod unity.

To get to the tomb, pilgrims have to pass through several gates. The tomb site has three courtyards arranged from north to south. Yard borders are indicated by height differences. The first yard is the lowest and the third yard is at the top. In the first yard, there is a gate with dragon statue ornaments on both stairs. In this yard, there are 56 ancient tombs with an irregular arrangement. The dragon head statue is estimated to be 600 years old. The head of the dragon, better known as Naga Giri, depicts a magical battle between Sunan Giri and a powerful hermit from the slopes of Mount Semeru [5]. The dragon's head symbolizes a sacred animal as well as has a deep, powerful, and moral meaning for spiritual life in the period before Islam entered Indonesia until now.

The second yard is north of the first one. Characterized by a gate made of red brick, in this courtyard, there are two terraces with different heights. Each is marked with an ancient tomb. The third yard is the most important part. In this yard, there is the tomb of Sunan Giri [6]. The tomb, a cupola with three roofs was built. The overlapping roof is a symbol of God's power and greatness.

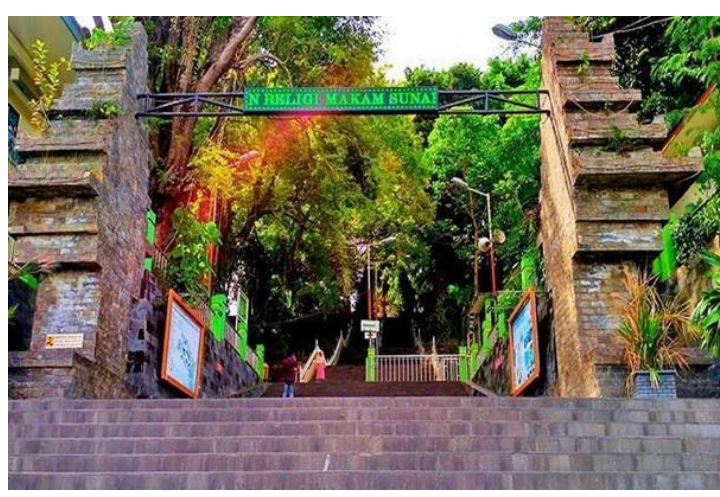

Figure 1. Stairs to the tomb

This refers to the position of Wali as an insan kamil (perfect human) as the embodiment of God. Judging from the shape of the building, Sunan Giri's tomb is like a temple consisting of the bottom, body, and roof. The roof is in the form of an overlapping roof. The terrace roof is a Hindu building art tradition that is known before Islam. The tomb building with a cupola and an overlapping roof that is similar to the Hindu-Islamic tradition can be understood as a form of a cultural shock to attract the sympathy of people who have not believed in Islam. On the one hand, the shape of the building does not conflict with Islamic values [7].

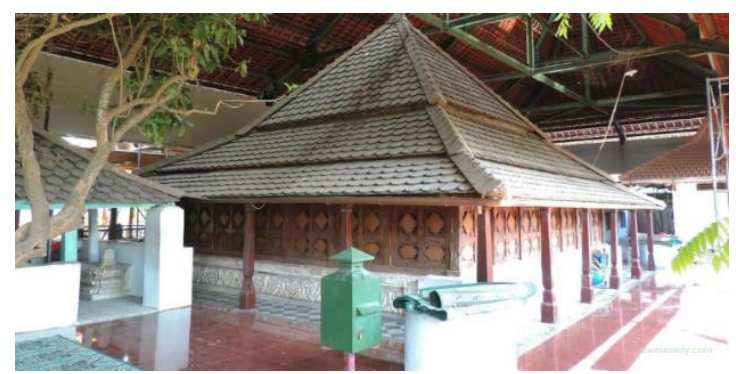

Figure 2. Tomb Shape

Philosophically, the arrangement of Sunan Giri Tomb can be divided into three parts, namely profane, transition, and sacred areas. The profane area is settled at the very front (parking lot, several stairs leading to the tomb used for souvenir and food stalls). Then, the transition room includes tombs of the students and their families. At the very back area (tomb of Sunan Giri and mosque) is a sacred space, with the highest sanctity value.

The sacred area is divided into two rooms, namely the space where the tomb of Sunan Giri and his family reside and the area of the Jami' Mosque. The tomb area of Sunan Giri and the tomb of his wife, children, and friends are the most sacred space. In this place, pilgrims perform prayers and dhikr [8]. In this space, apart from the cupola building for the tomb of Sunan Giri, there is also the cupola of the tomb of his wife and children, as well as the pavilion building. In this site, there are also the tombs of Sunan Giri family namely Sunan Dalem, Sunan Tengah, Sunan Kulon, Nyai Ageng Selo, and others. The tomb building is equipped with decorations 
that are a continuation of the pre-Islamic building tradition. This tomb is built based on a cosmological concept that puts forward parallels or balances between the macrocosm and microcosm

\subsection{Pilgrims' spiritual practices at the tomb during} The Pandemic

Sunan Giri tourism is also the most visited tourism in Gresik Regency. Based on data from the Department of Tourism and Culture, the average number of visitors to Sunan Giri Religious Tourism per month reaches 100,000 to 200,000 people. The number of pilgrims every day reaches 5,000 visitors, which are dominated by visitors from Java, Sumatra, and Kalimantan islands. Generally, religious tourism visitors to the Tomb of Sunan Giri follow the Wali Songo tour, where the Tomb of Sunan Giri is one of the tourist destinations in the tour package. Since the pandemic, the average number of visitors is 0 to 80,000 people per month [9] However, since August, Sunan Giri Religious Tourism has been reopened. To maintain the safety and comfort of visitors, the reopening of this tour is supported by several changes following the health protocol, namely: (1) tourist restrictions; (2) checking body temperature; (3) there are hand washing stations at several points, entrances, stairs, and exits; (4) Visitors are required to wear masks and maintain a distance, (5) restrictions on operating hours; and (6) restrictions on pilgrimage times (Department of Tourism and Culture, 2020).

Pilgrimage is one of the Islamic rites that has been rooted in Indonesian society [11]. The pandemic period did not dampen the desire of the pilgrims to make a pilgrimage to the tomb. Historically, the conception of this pilgrimage is influenced by the Sunni tradition, where the karamah (the privilege from God) of Wali is believed to be able to help solve problems faced by people [12]. This belief in karamah applies not only when wali is still alive, but also when wali has died. This is manifested through a pilgrimage to the tomb where wali is buried. This ritual has become a tradition of Indonesian Sunni Muslims that is embodied in an organization called Nahdlatul Ulama '(NU). The nahdhiyin community, the term used to describe NU followers, has a strong Sunni tradition, especially in matters of Sufism and Thoriqoh (Spritual Path).

In general, the activities of the pilgrims in the tomb perform three rituals namely: tawassul, reading Yasin, Tahlil, and prayer. First, in language, tawassul means intermediary and closer [13]. The meaning of tawassul which is understood by Muslims is to pray to Allah through an intermediary, whether the intermediary is in the form of good deeds or through pious people who are considered to have a closer position to Allah. In this context, tawassul by making a pilgrimage to the tomb of Sunan Giri is intended to ask God through the intermediary of Sunan Giri who is God's love and has a noble position by His side. Sunan Giri's closeness to God is believed to be the way to grant prayers. Tawassul is one of the efforts so that the prayers are accepted and granted by Allah SWT.

A Muslim who believes in praying to God makes the intermediary in the form of something he loves and believes that Allah SWT also loves the intercession. In the context of tawassul with people who have died, there are two spectrums of views. The first view, tawassul is something that is recommended, not a ritual that associates partners with God because the position of tawassul is only a door and intermediary in praying to God. Tawassul is not a shirk, because people who have tawasul believe that only Allah will answer all prayers. Some pilgrims perform tawassul in a standing position in front of the tomb as a form of respect. Others sat solemnly towards the grave [14].

The second view is from Wahhabi-Salafi circles who understand that tawassul with the position of a pious person who has died is an act of partnering with God and is forbidden. The prohibition is viewed from tawassul as the behavior of swearing by other than Allah, while swearing by other than Allah is unlawful, even including shirk, namely shirk asghar (minor shirk) and the belief that someone has rights over God. Tawasul is seen by this group as a fall into haram, even shirk. These two currents of understanding illustrate the polarization of Indonesian Muslims into Nahdliyyin and Wahabi-Salafi communities.

Second, it is reading Yasin (one of surah in Qur'an). Surah Yasin is the $36^{\text {th }}$ surah of the Qur'an that consists of 83 verses. Surah Yasin is the most famous surah among Muslims. Among the virtues of reading Surah Yasin is to make it easier for death, cure diseases, and speed up the fulfillment of all desires/needs. Yasin is sometimes read individually or together in front of someone who is critically ill or facing death. The tradition is based on the hadith of Prophet "Read Yasin next to your brother who is dying." The understanding of this hadith is the recommendation to read Yasin to people who are facing death and those who have died, either before the funeral or on the grave.

Third, it is tahlil and prayer. Tahlil or tahlilan has become a tradition among Nahdliyyin in Indonesia to pray for families who have died or grave experts in general. Tahlil consists of a series of selected readings from surah and verses of Qur'an, shalawat (praise to Prophet Muhammad), istighfar (ask for forgiveness), and thayyibah (dhikr to Allah). Tahlil is not only to pray for relatives who have died, but also for the human who wants to get safety and happiness in this world and the hereafter. The recitation of tahlil is usually done in order to pray for new bodies in their graves, people who have been buried for a long time, and people in commemoration of 1-7 days, 15 days, 40 days, 100 days, and 1000 days after death. Tahlil is also carried out in other religious ritual activities.

During the pandemic, there were several changes in the behavior of pilgrims, namely: (1) the duration of the pilgrimage was limited to 15 minutes; (2) keep the distance between pilgrims, especially pilgrims who come in groups; (3) limiting the number of pilgrims within the 
main area of the tomb; (4) "male" pilgrims are not allowed to spend the night; and (5) short reading of tawassul and tahlil

Table 1. The Behavior of the Pilgrims

\begin{tabular}{|l|l|l|}
\hline $\begin{array}{l}\text { Types of } \\
\text { Pilgrims }\end{array}$ & $\begin{array}{l}\text { How to Read } \\
\text { Prayers }\end{array}$ & \multicolumn{1}{|c|}{ Activities } \\
\hline $\begin{array}{l}\text { Individua } \\
1\end{array}$ & $\begin{array}{l}\text { A soft voice } \\
\text { with a duration } \\
\text { of 15-45 } \\
\text { minutes }\end{array}$ & $\begin{array}{l}\text { Tawassul, reading } \\
\text { Yasin, Tahlil, and } \\
\text { prayer or abbreviated } \\
\text { Tawassul, Tahlil, and } \\
\text { prayer }\end{array}$ \\
\hline $\begin{array}{l}\text { Individua } \\
\text { l Lelaku }\end{array}$ & $\begin{array}{l}\text { Soft voice and } \\
\text { spending the } \\
\text { whole night in } \\
\text { the tomb for a } \\
\text { few days }\end{array}$ & $\begin{array}{l}\text { Certain practices } \\
\text { according to the } \\
\text { spirection of the } \\
\text { spiritual teacher }\end{array}$ \\
\hline $\begin{array}{l}\text { Small/lar } \\
\text { ge group }\end{array}$ & $\begin{array}{l}\text { Louder voice } \\
\text { following the } \\
\text { leader's reading } \\
\text { with a duration } \\
\text { of 15 - 45 } \\
\text { minutes }\end{array}$ & $\begin{array}{l}\text { Tawassul, reading } \\
\text { Yasin, Tahlil, and } \\
\text { prayer or abbreviated } \\
\text { prayer. Partly doing } \\
\text { khatmil and and } \\
\text { (Reading Qur'an as a } \\
\text { whole conducted by } \\
\text { many people in turn) }\end{array}$ \\
\hline
\end{tabular}

In addition to reading tawassul, Yasin, tahil, and prayer, there are also pilgrims who perform lelaku (spiritual activities) at the tomb, meditate by doing wirid and dhikr, and do the practices recommended by their spiritual teacher for the sake of achieving the true meaning of life and for the safe life in the world and in the hereafter. Such a picture of life is inseparable from the characteristics of a society that still maintains the tradition of kejawen life.

The habits of Javanese is tied to an aspect of belief in certain things that make the behavior of Javanese people dominated by a mystical system. The mystical Javanese perspectives are also inseparable from a strong belief in a very strong myth. Sacred objects are believed to bring blessings. One of these sacred places is a tomb, especially the tombs of Wali, religious leaders, and other figures. A spiritual journey from one tomb to another is also carried out by someone to start a spiritual odyssey to know the essence of self and God.

The concept of sacred usually involves a sacred tomb where Wali can be an intermediary to pray or ask fervently. The Javanese Islamic community strongly believes that Wali has the power to give blessings and help those who face religious problems. This is what motivates pilgrims to come to Wali's tomb to hope that the problems can be solved and blessed life.

In a wider context, the sacred Wali's tomb will be a place for fulfilling the pilgrim's religious or spiritual needs, intelligence, wealth, safety, and strength. This later becomes a strong spiritual tradition in the community, so that pilgrimage activities are not only related to remembering death and imitating the morals of Wali, but also it becomes a medium for meeting both material and spiritual needs

\section{CONCLUSION}

In conclusion, Sunan Giri's tomb is on the top of a hill as a symbol of the high position of Wali and the unity between the macrocosm and microcosm. The shape of the tomb and its ornaments are a combination of HinduIslamic elements. In addition, there are three types of pilgrims, namely individual, individual-lelaku, and congregational. The activities carried out are generally reading tawassul, surah Yasin, tahlil, and prayer. Pilgrimage activities are not only to remember death and imitate the morals of Wali, but also it becomes a medium for meeting both material and spiritual needs. The findings of this study are the continuity of Hindu and Islamic traditions in the form of Wali's tomb.

\section{ACKNOWLEDGMENTS}

Thank you to the Rector of Universitas Negeri Surabaya for supporting this research

\section{REFERENCES}

[1] Anita, D. (2014) Walisongo: Mengislamkan Tanah Jawa Suatu Kajian. Wahana Akademika: Vol. 1 No. 2, Oktober 2014, $243-266$.

[2] De Graff. (1985). Ereste Muslimen Vosrertendomen Op Java. Studeien Over De Statkundige Geschidenis Van De 15de EN 16de Eeww. Jakarta: PT Grafiti, 1985.

[3] Santosa, B., et. Al. (2014).Dinamika Ruang Wisata Religi Makam Sunan Giri Di Kabupaten Gresik. El Harakah Vol.16 No.2 Tahun 2014

[4] Hariyoko, Y., et al. (2021). Evaluasi Kebijakan Pembangunan Wisata Religi di Kabupaten Gresik. Publica: Jurnal Pemikiran Administrasi Negara. Vol 13, No 1 (2021) P-ISSN 2085-6555 Vol 13 No. 1 | Juni 2021:

[5] Subadyo. T. (2018) Pelestarian Situs Makam Sunan Giri Secara Berkelanjutan. Mintakat: Jurnal Arsitektur. Vol 19, No 1 (2018).

[6] (https://hpn2019.id/wisata-religi-sunan-giri/).

[7] (http://digilib.uinsby.ac.id/4920/9/Bab\%204.pdf).

[8] Siswayanti, N. (2016). Akulturasi Budaya pada Arsitektur Masjid Sunan Giri. Jurnal Lektur Keagamaan, 14(2), 299-326. https://doi.org/10.31291/jlk.v14i2.503.

[9] Interview with The personnel of Department of Tourism and Culture Gresik, 2021. 
[10] Interview with The personnel of Department of Tourism and Culture Gresik, 2021.

[11] Faidah, M/ et.al. (2021). Exploring Muslim Tourist Needs at Halal Spa Facilities to Support Indonesia's Sharia Tourism, International Journal of Religious Tourism and Pilgrimage: Vol. 9: Iss. 1, Article 11. doi:https://doi.org/10.21427/qme4-g097.

[12] Geertz, C. (1989). Abangan, Santri, Priyayi dalam Masyarakat Jawa, Jakarta: Pustaka Jaya, 1989.

[13] Ahmad. K. A. (2015). Tradisi Ziarah: Antara Spiritualitas, Dakwah Dan Pariwisata. Jurnal Bimas Islam 8, no. 2 (June 30, 2015): 389-411. Accessed July 26 , 2021. https://103.7.12.120/jbi/article/view/179.

[14] Asmaran, A. (2018). Membaca Fenomena Ziarah Wali Di Indonesia: Memahami Tradisi Tabarruk Dan Tawassul. Al-Banjari: Jurnal Ilmiah Ilmu-Ilmu Keislaman, $\quad 17(2), \quad$ 173-200. doi:http://dx.doi.org/10.18592/albanjari.v17i2.2128.

[15] Marwoto. (2016). Spiritual Phenomena in the Town of Demak, Procedia - Social and Behavioral Sciences, Volume 227, 2016, Pages 451-457, https://doi.org/10.1016/j.sbspro.2016.06.100.

[16] Budiarto, A. et. Al. (2016). The Urban Heritage of Masjid Sunan Ampel Surabaya, toward the Intelligent Urbanism Development, Procedia Social and Behavioral Sciences, Volume 227, 2016, Pages 601-608, https://doi.org/10.1016/j.sbspro.2016.06.121. 